University of Chicago Law School

Chicago Unbound

Journal Articles

Faculty Scholarship

1904

\title{
Liability of a Master to Third Persons for the Negligence of a Stranger Assisting His Servant
}

Floyd R. Mechem

Follow this and additional works at: https://chicagounbound.uchicago.edu/journal_articles

Part of the Law Commons

\section{Recommended Citation}

Floyd R. Mechem, "Liability of a Master to Third Persons for the Negligence of a Stranger Assisting His Servant," 3 Michigan Law Review 198 (1904).

This Article is brought to you for free and open access by the Faculty Scholarship at Chicago Unbound. It has been accepted for inclusion in Journal Articles by an authorized administrator of Chicago Unbound. For more information, please contact unbound@law.uchicago.edu. 


\section{ASSISTING HIS SERVANT}

SPEAKING generally, one person can only be liable for the $S$ negligence of another when he stands toward that other in the relation of master and servant.

Speaking generally, also, one person can become the servant of another only with the latter's express or implied consent. That consent may be given by him in person or by some agent to whom the power of appointing servants for him has been delegated. Such a power may be expressly conferred or it may arise by implication. There is, for example, a large and familiar class of cases, not now necessary to be considered, wherein power in a certain agent to employ sub-agents or servants will be implied. The case of the agent given general control or management of some business or enterprise to the proper conduct of which sub-agents or servants are necessary, may be cited as an illustration. Another well recognized illustration is found in the case of merely mechanical or - ministerial acts. Thus an agent, who has himself passed upon all those matters which involve judgment or discretion, may bind his principal even though he confides to a sub-agent the execution of the parts which are mechanical or ministerial merely. The general rule, however, is, that an agent or servant has no implied authority to delegate his undertaking to another; and it is very clear that an ordinary servant has usually no implied power either to substitute some one else in his place or to employ some one else to assist him, in such a way as to make the person so employed the servant of his master.

In the contract field, this doctrine, with certain well recognized exceptions, is constantly enforced, and a principal is not liable upon a contract made in his behalf by one to whom his agent, without his consent, has attempted to delegate his authority, even though he might have been liable upon that very contract if it had been made by his agent.

Does the same rule extend to torts? And, more specifically, is the master liable for the negligence of one to whom his servant, without special authority, has attempted to delegate his undertaking in whole or in part?

To this question a variety of answers have been given. Thus Messrs. Shearman and Redfield in their well known work on Negligence ${ }^{1}$ say:-

“* * * A question of some difficulty may .arise, where a ser-

\footnotetext{
1 (5th ed.) $\$ \times 57$.
} 
vant, without having any real or ostensible authority to do so, employs an assistant, by whose negligence, in the performance of work assigned to the former servant, a third person is injured. The master would not be bound by a contract made in his name by such a sub-agent, even though it were exactly such as he had authorized his own servant to make; and from this it might not unreasonably be inferred that he could not be made liable for the torts of one whose contracts would not bind him. 'On the other hand, manifest inconvenience is certain to ensue to the public at large from thus shifting the responsibility from masters, who, as a class, are able to meet it, and who receive the benefit of the service, upon servants who, as a class, are entirely unable to compensate for the injuries thus caused. Public policy, therefore, requires that masters should be held liable for the consequences in such cases; and so the courts have held, although without laying down any general rule upon the subject."

So, in the first edition of the American and English Encyclopedia of $\mathrm{Law}_{\mathrm{r}}{ }^{2}$ a rule was given which has been cited in subsequent cases as follows:-

"Where a servant employs a third person to perform an act within the servant's employment, and injury results to another, the master is liable the same as though his servant employed no agent."

Mr. Wood in his work on Master and Servant ${ }^{3}$ states the rule still more broadly, thus:-

"If the servant employs another person to do his work or to assist him therein, the master is liable for an injury resulting from such person's acts."

The first statement, as will be observed, suggests no other reason than the requirement of so-called public policy that a pecuniarily responsible defendant be found: and the second and especially the third seems to lead to some rather startling consequences if it be applied without qualification.

Such statements as these, therefore, seem to suggest further investigation of the subject; and it may be worth while to review with some fulness the leading cases which involve the question. .In doing this, the cases will first be stated without comment.

One of the earliest cases upon the subject is that of Booth v.

In the second edition of this work, Vol. 20, p. 177 , the rule is given thus: "A master is liable for the negligence of a person whom the servant has procured to aid him in his work, where the negligent act resulting in the injury complained of occurred in the course of the work."

$=14$ Am. \& Eng. Encyc. of Law, p. 8ro, quoted in Tennessee Coal, etc., Co. v. Hayes, 97 Ala. 201, Ia So. 98.

3 ( $2 \mathrm{~d}$ ed.) $\$ 30 \AA$ 
Mister, ${ }^{4}$ decided in 1835 . The declaration stated that the cart of the defendant was so negligently driven by the defendant's servant that it struck against a cabriolet in which the plantiff was riding, whereby the plaintiff was injured. It appeared that a servant of the defendant, whose duty it was to have charge of the cart, was riding in the cart at the time the accident occurred, but that another person, who was not in the defendant's service, was driving the cart, the servant having given him the reins. It was urged for the defendant that the defendant was not liable on the ground that, as a person not in his service was driving at the time of the accident, the allegation that the cart was driven by the defendant's servant was not sustained by the evidence. Lord Abinger, however, was of the contrary opinion, saying:-

"As the defendant's servant was in the cart, I think that the reins being held by another man makes no difference. It was the same as if the servant had held them himself."

In 1859 , the case of Simons v. Monier ${ }^{5}$ came before the Supreme Court of New York. It appeared that the defendant's servant, one Seth Terry, was employed to clear up some woodland for tillage. In the process of clearing he had cut a large quantity of brush and piled it in heaps for burning. On a day in a summer of unprecedented drouth he directed his son, John Terry, "a lad then living with him and subject to his control," to set fire to the brush heaps, which he immediately did. The fire spread to the plaintiff's adjoining premises and caused the injury for which the action was brought. The chief defense was that John Terry was not the servant of the defendant, but of Seth Terry, and that the defendant was in no way responsible for his acts. The trial court, however, charged in substance that the act of John Terry in setting the fire was the act of Seth Terry, his father, and that if it was negligent to set the fire at that time, the plaintiff was entitled to recover. This charge was approved by the supreme court, which said, per Johnson, J.:-

"The setting of the fire, which the jury found was a negligent act, was done by John at the time, by the express direction of his father. Upon this state of facts, the judge, I think, was clearly right in instructing the jury that the act of setting the fire was the act of the father. It was his immediate personal act; for although it was done by the hand of the son, the hand was directed, guided and controlled by the mind and will of the father. It was the father's will and volition exclusively. It was his carelessness and not the carelessness of the son. It was precisely as much the act of

7 C. \& P. 66. See also Randleson 0. Murray, 8 Ad. \& El. rog.

\$29 Barb. 4 rg. 
the father as though he had used some other means or instrument in conveying the fire and kindling the flame. This being so, the defendant was clearly liable, if the setting of the fire was within the scope of the employment of Seth Terry as a hired servant upon the farm."

In the following year there came before the Court of Appeals of New York the case of Althorf v. Wolfe. ${ }^{6}$ It appeared in that case that the defendant was the owner and occupant of a dwelling house abutting upon a public street in the city of New York. During the winter the roof had become weighted with snow and ice, and upon a certain day the defendant instructed his coachman, one Fagan, to shovel off the accumulation, giving him no specific instructions as to how the work should be done or where the snow and ice should be thrown. It appeared, however, that a former coachman on a similar occasion had thrown the snow and ice into the area at the rear of the house. After giving these instructions the defendant went away to attend to his business during the day. Before going upon the roof, Fagan was sent by the defendant's wife upon some errand, and in returning met an acquaintance, one Cashan, whom he asked, apparently as a mere act of friendship or companionship, to come and assist him. Fagan provided shovels for both and the two went upon the roof and began to throw the snow and ice into the street in front of the house. (Defendant's family was evidently at home though it does not appear that any of them knew that Cashan was assisting Fagan.) While so engaged, a piece of ice apparently, though not certainly, thrown by Cashan struck a passer-by upon the street below and caused his death, and the action was by his administrator to recover damages. The defendant asked the court to charge that if the death resulted from the act of Cashan, and he was employed by Fagan without the authority of the defendant, the defendant was not liable. The court refused the request, and charged in substance that the defendant was responsible for the negligence of either. Two opinions were written in the case, one by Wright, J., and the other by Denio, J., both confirming the judgment of the court below. 'Wright, J., placed the liability of the defendant on three grounds: first, that the defendant's servant, having been instructed generally to throw the snow from the roof of the house, had implied authority to do it in the usual way, and that this involved the authority to employ an assistant if necessary; second, that the defendant as the owner of the premises was responsible for what went on thereon, either by his servant or by others admitted to the premises with the tacit consent of the mem-

\footnotetext{
${ }^{\circ} 22$ N. Y. 355.
} 
bers of the defendant's household; and thirdly, that the act of Cashan, as in the two cases already considered, was to be regarded as the act of Fagan. Booth v. Mister, supra, was cited and relied upon. Denio, J., placed the liability chiefly upon the last ground, saying,-

"The defendant does not and cannot deny that he is responsible for the negligent and wrongful acts of Fagan. If it had been certain that it was that person, and not Cashan, who threw the piece of ice which killed the deceased, the defendant clearly would have been responsible. Instead of accomplishing the mischief in that manner, Fagan, by a negligent and improper act, enabled Cashan to do it. If we keep in mind that the defendant is responsible for the acts of Fagan, and that Fagan took his comrade on to the roof and thus enabled the latter to do the mischief, it is difficult to discover any principle which will shield the defendant from responsibility. It is not necessary to consider Cashan as the defendant's servant. $\mathrm{He}$ was, rather, the instrument by which Fagan, for whose conduct the defendant was undeniably responsible, did the wrong." Two judges dissented.

This case has been followed in other cases in New Yörk which more or less closely resemble it, as, for example, in Gleason v. Amsdell, ${ }^{7}$ decided in I88o. It there appeared that while a truck owned by the defendants was standing in front of their place of business loaded with heavy barrels in charge of their driver, he was directed by $B$, one of the defendant's chief employees, to unload it. As the driver wanted to go to dinner, he asked one $S$ to unload the truck, which $S$ proceeded to do, $B$ looking on from a window. $S$ was not regularly in the employment of the defendants, but was accustomed to be about their place of business, and there was evidence that he had sometimes done small jobs of work there for which he had been paid, sometimes by $B$ and sometimes by one of the defendants' drivers. In unloading the truck $\mathrm{S}$ negligently caused a barrel to fall upon a passer-by and did the injury for which recovery was sought from the defendants. The defense was that $S$ was not the servant of the defendants but the Court of Common Pleas held the defendants responsible, citing Booth v. Mister and Althorf v. Wolfe, supra, upon two grounds: first, that there was some evidence that he was employed with the defendants' knowledge and consent; and secondly, that the act under the circumstances must be regarded as the act of the defendants' driver.

Wellman v. Miner, ${ }^{8}$ decided in 1897 , also applies the same prin-

7 Daly, 393.

3 I9 Misc. 644 . 
ciples. The defendant was the proprietor of a theatre, and employed an attendant, one Cole, to stand at the entrance and open the door of the carriages of patrons as they arrived. Cole had made an arrangement with one Brown to assist him in this service in consideration of a division of the "tips" received. Brown had been so employed for a number of weeks, and apparently wore the defendant's livery. Upon the day in question, the plaintiff approached the theatre in his carriage, when through the negligence of either Cole or Brown, but apparently of Brown, the carriage door was opened against a post and the carriage injured. The same defense was made in this case as in the previous ones, namely, that Brown was not the servant of the defendant. A judgment for the plaintiff, however, was affirmed by the Appellate Term of the Supreme Court upon two grounds : first, that an actual employment of Brown might properly be inferred by the jury in view of the length of time during which Brown had been openly performing this duty; and secondly, as in Althorf v. Wolfe, that the master is "liable for the negligent act of an individual whom the servant had invited to aid him in the task imposed by the master, the negligence having occurred in the course of the work."

The rule of Althorf v. Wolfe was also applied in Hill v. Sheehan, ${ }^{9}$ decided by the Superior Court of Buffalo in I892. The defendant was a livery and boarding stable keeper and it was part of his undertaking to deliver to patrons when called for the horses boarding at his stable. The horse of a certain patron being called for, the defendant entrusted it to his servant to be delivered, the latter having positive instructions not to permit anybody else to drive the horse to deliver it to the owner. Instead of delivering it in person, however, the servant entrusted it to an acquaintance, one Kreuger, for delivery, who drove the horse in such a negligent manner that the plaintiff was injured. The liability of the defendant was sustained upon the ground that the injury was caused by the violation by defendant's servant of the instructions given him as to the manner in which the work should be performed, and also upon the ground that the facts brought the case within the principle of Althorf v. Wolfe. Said the court:-

"It is insisted that Kreuger was in no sense defendant's servant, and consequently he cannot be made liable for his acts. This overlooks the fact that by the act of the servant who was in charge, an instrument, $i$.e., Kreuger, was used for the prosecution of the mas-

\footnotetext{
20 N. Y. Supplement, 529. Kilroy v. Canal Co., I2I N. Y. 22, 24 N. E. 192, and Cosgrove v. Ogden, 49 N. Y. 255, were chiefly relied upon, and Hexamer v. Webb, ror N. Y. 377,4 N. E. 755 , and King $v$. Railroad Co., 66 N. Y. 181, were distinguished.
} 
ter's business, and that such instrument inflicted the injury. It is not essential, under such circumstances, that the relation of master and servant should exist, in order to fasten responsibility. It is sufficient when it appears that the master's business is being prosecuted by the instrument used."

The question was also involved in Bank of California v. Western Union Telegraph Company, ${ }^{10}$ decided by the Supreme Court of California in I877. It there appeared that one Washburn was the agent of the telegraph company at a certain town, and that he had frequently employed one Crowell to assist him in the office, but Crowell was never employed by the telegraph company in any capacity. While so assisting Washburn, Crowell frequently sent and received messages over the defendant's wires. Upon a certain occasion Crowell, taking advantage of his opportunity while Washburn was absent, and without his knowledge or consent, sent a fictitious telegram to the plaintiff directing the delivery of money, which Crowell received and with which he absconded. The action was by the bank against the telegraph company to recover for the loss of this money. The defense was that Crowell was in no sense the servant of the defendant, but it was held, citing Althorf v. $W o l f e$, that the defendant was responsible, on the ground that the proximate cause of the plaintiff's loss was the negligence of Washburn, the defendant's agent. It was part of his duty to keep any unauthorized person from using the defendant's wires. "He failed to discharge this duty and the principal is equally responsible whether the placing of Crowell in charge was a wrongful act committed as part of the transaction of the business, or was mere negligence."

\footnotetext{
${ }^{10} 52$ Cal. 280 .

Lakin v. Oregon Pac. R. Co., 15 Oreg. 220, I5 Pac. 64I, may be cited in the same connection. There a passenger had been injured through the carelessness of a person who was on the engine, in pursuance of the directions of a superior agent, for the purpose of learn. ing its use. There was testimony that this agent had no authority to give any such directions; but it appeared that the learner was managing the engine with the acquiescence and consent of the servants to whom the conduct of the train had been delegated and the safety of the passengers confided, and it was held that their failure to perform the carrier's duty of safe carriage rendered the company liable. There was no discussion of the particular question here under consideration.

The same principle controls Carson $v$. Leathers, 57 Miss. 650, where a steamboat passenger was led to disembark at the wrong place through the error of one who the passenger supposed was an authorized employee, but who was really only a friend of the clerk gratuitously assisting him in the performance of his duty to see that passengers were properly notified when their destination was reached.

In Andrews v. Boedecker, 126 I11. 605, 18 N. E. 65I, 9 Am. St. Rep. 649, the injury was the result of the joint negligence of defendant's servants and another who voluntarily assisted them. It was held to be immaterial whether this assistant was regarded as a servant of the defendant or not.
} 
The same question was also involved in Campbell v. Trimble, ${ }^{11}$ decided by the Supreme Court of Texas in 1889. There the injury was caused to the plaintiff's colt by its being kicked by a vicious horse belonging to the defendant and entrusted to the charge of his servant, the defense, among other things, being that at the time of the injury the horse was not in charge of this servant, but was being controlled by a third person to whom the servant, without the defendant's knowledge or consent, had entrusted it. It was held, however, that even if this were the fact, it did not in any manner relieve the defendant from liability.

In Fick v. Chicago and Northwestern Railway Company, ${ }^{12}$ decided by the Supreme Court of Wisconsin in I887, the action was to recover damages for an assault upon the plaintiff alleged to have been committed by the defendant's ticket agent. It appeared, however, that the person who committed the assault was not the ticket agent, but his brother, whom he had temporarily placed in charge of the ticket office. It was contended here, as in the other cases, that the injury was not committed by the defendant's servant, but it was held that as the person who did the injury was in the ticket office performing the duties of ticket agent with the consent and under the direction of the person employed in that capacity, his act must be regarded as an act of the defendant's servant.

The same point is also involved in Appel v. Eaton, ${ }^{13}$ which came before the St. Louis Court of Appeals in 1902. The defendant was the contractor for the construction and equipment of two elevators in a ten-story building. One elevator was completed and running. The other was in place, but the work upon the shaft was not entirely completed. Upon the day in question, workmen were engaged in the elevator shaft at the seventh floor. An employee of defendant was also engaged in finishing a brick casing about the bottom of the elevator shaft. Having finished his work, and desiring to get the elevator out of his way in order that he might clean up the debris beneath it, he asked a friend and former employee of the defendant, who happened to come into the building at that moment, to move the elevator up out of his way. This friend ran the elevator up to the second floor to find a friend of his, and, not finding him on the second floor, he continued on to the third floor. At this point an outsider appeared, who requested that he be taken up in the elevator. He was told that the elevator was not yet in use and directed to go to the other, but, insisting, he was taken

\footnotetext{
"11 75 Tex. 270.

1268 Wis. 469,32 N. W. 527.

${ }^{13} 97$ Mo. App. 428, 7 I S. W. 741 .
} 
into the elevator; and in going up the elevator struck the scaffold on which the men first mentioned were at work, causing one of them to fall to his death. The action was brought by his administrator to recover damages. The defendant's servant who requested his friend to move the elevator out of his way knew that the workmen were engaged higher up in the shaft, but he did not inform his friend of that fact, and he apparently did not contemplate that the elevator would be raised so far. A majority of the court held that the defendant was responsible, upon the ground that the negligence was the negligence of the servant in charge of the work of . enclosing the elevator shaft. Moving the elevator to the extent convenient or necessary to enable him to perform his work, was held to be within the scope of his employment. It was his duty, however, to give precautions against running the elevator too high, and his failure to give such precaution was negligence.

On the other hand, in Mangan v. Foley, ${ }^{14}$ decided by the St. Louis Court of Appeals in I888, a different conclusion was reached. It there appeared that the defendant was the owner of a coal wagon and team and employed a servant regularly to drive it. Upon the day in question this driver, instead of going with the team in person, entrusted it to a friend with the request that he take out a load or two for the driver. While the friend was driving the team in pursuance of this request, he ran down and killed the plaintiff's child. It was held that the defendant was not liable, as the driver was not his servant, and as the act of the driver in confiding the team to his friend under these circumstances could not be deemed an act within the scope of his employment.

Views not to be reconciled with those expressed in several of the foregoing cases were also expressed in James v. Muehleback, ${ }^{15}$ decided by the Kansas City Court of Appeals in I889, though a judgment against the master was affirmed. It appeared that the driver of defendants' wagon loaded with empty barrels took one Ehrhard, an acquaintance, upon the wagon, who merely wanted a ride. On the way the load became disarranged and the wagon was stopped to readjust it. In doing so it became desirable to take or throw off a number of barrels. Ehrhard assisted in this, apparently at the driver's request, and one of the barrels thrown by him struck and injured the plaintiff. In discussing the question the court said :-

"In cases of this nature the test is to ascertain the relation between

1433 Mo. App. 250.

10 34 Mo. App. 512. Neither of the last two cases was referred to in the case in 97 MLo. App. 
the party charged and the party actually committing the injury. Unless the relation of master and servant exists between them, the act of the one creates no liability on the other. The man Ehrhard was not the servant of defendants; they had not employed him or authorized his employment, nor did they know of his presence with their driver. *** If he was defendants' servant, it was through an implied authority in the driver to hire him.

"To say authority exists in a teamster to hire other servants for his master would be an unreasonable and extreme statement; it would imply also the right to fix compensation and discharge servants,-in other words, would make of him a vice-principal. Whether a servant, however inferior, would have authority in a sudden emergency to hire assistance in order to save the property of which he was in charge, or prevent its doing some impending harm, is not necessary here to consider, as such question does not arise in this case."

The court then proceeded to discuss the authorities, especially Althorf v. Wolfe, which was deemed to rest substantially upon the ground that the defendant was responsible for what occurred upon his premises, and said:-

"The result of the case is, that while the facts are in many respects applicable to the case at bar, the ground upon which the decision has been put does not aid us in the solution of the present question. The same result might, perhaps, have been reached in that case for a different reason. The act of the volunteer was substantially the act of the servant, for he was immediately present, standing by, and directed that the ice be thrown into the street; it was as much his act as if done by his own hand. If a servant in charge of his master's carriage should take a stranger with him into the driver's seat, hand him the reins and tell him to drive at a run, and an injury happen in consequence of the speed, the master must answer for the damage, for the negligence was that of his servant. But not so if the servant had quit the carriage and substituted the stranger in charge generally, in his stead, without the knowledge of the master. For if an injury happen, it is not the act of the servant for whom only is the master liable."

Booth v. Mister and Simons v. Monier were also discussed and approved upon the ground that the act complained of was in fact the act of the servant though done through the stranger as a mere instrument. The case at bar was held to rest properly on that ground.

"Our conclusion is that Ehrhard was not the servant of the defendants, and if they are to be held liable in this case it must be 
through the act of the driver. If, therefore, the driver himself negligently threw the barrel, the case is settled at once against defendants; but if Ehrhard threw it, it must appear that he was directed or requested to do so by the driver. Such direction or request need not, necessarily, be by express words directed to Ehrhard by the driver, but the act must be shown to have been done for the driver and with his assent and by reason of his wish or desire."

There being evidence tending to show that this was the case, and the jury having evidently found that such was the fact, the judgment for the plaintiff was affirmed.

Long v. Richmond, ${ }^{16}$ decided by the Appellate Division of the Supreme Court of New York in 1902, and affirmed by a majority of the Court of Appeals without an opinion, is also in point. There it appeared that the defendant had two polo ponies which he wished taken to a certain place. He instructed his servant to ride the chestnut pony and lead the gray one and not let any one ride the gray pony either going or coming. In violation of these instructions and without defendant's knowledge, his servant obtained the assistance of one Eckert and permitted him to ride the gray pony. While so riding, Eckert managed the pony so negligently that he did injury to the plaintiff for which this action was brought. The plaintiff recovered on the trial but the judgment was reversed by the Appellate Division, one judge dissenting. The position of the majority was that Eckert could not be regarded as the defendant's servant, and that the servant instructed to take the ponies to the place in question had no authority to employ an assistant or substitute. They said:-

"We can conceive of no rule of law or of equity which will permit a servant, in violation of his master's instructions and without his knowledge or consent, to allow other persons to do his work which he is employed to do, without any necessity therefor, and thus make the master liable for the negligent acts of such other persons."

Althorf v. Wolfe was distinguished on the ground that there the servant had been left to do the work without any instructions and that the presence of the assistant must have been known to members of the defendant's family. The dissenting judge was of the opinion that the case presented merely an instance of a servant doing the thing directed but violating instructions as to the manner of doing it; and that the case could not be distinguished from Hill v. Sheehan, hereinbefore referred to.

1"i 68 N. Y. App. Div. 466,73 N. Y. Supp. 912 ; affirmed, 175 N. Y. 495. 
In Groilliam v. Twist, ${ }^{17}$ decided by the English Court of Appeal in 1895 , a substitute had been employed under the following circumstances: The defendants were the proprietors of an omnibus line. One of their omnibuses had gone out in charge of its driver, Harrison. While he was driving a police inspector, believing him to be under the influence of liquor and unfit to drive, stopped him and ordered him to discontinue driving. The omnibus at this time was about a quarter of a mile from the defendants' yards. One Veares, who had formerly been a driver for defendants but who was not now in their employ, happened to be standing by, and volunteered to drive the omnibus to the yards. Harrison, the driver who had been removed, and the conductor of the omnibus acquiesced, and Veares started to drive to the yards. On the way he carelessly drove over and injured the plaintiff, and this action resulted. It was contended by the plaintiff that Veares was the defendants' servant. It was conceded that ordinarily one servant has no implied power to delegate his undertaking to another so as to make the latter the servant of the former's master; but it was contended that in cases of "necessity" such a power exists. The court, however, held that that doctrine could not be applied to this case. Smith, L. J., in his opinion, said :-

"The question is whether under the circumstances of this case it was within the scope of Harrison's employment to put up Veares to drive the omnibus as he did. If it was not, his employers are not liable. It is clear that it is not prima facie within the scope of a coachman's employment to delegate the duty of driving to other persons. But it was argued that circumstances might exist which would constitute the coachman an agent of necessity on behalf of his master to employ some one else to drive, and that under such circumstances he would have authority to do so. To constitute a person an agent of necessity he must be unable to communicate with his employer; he cannot be such an agent if he is in a position to do so. The impossibility of communicating with the principal is the foundation of the doctrine of an agent of necessity. $* * *$ When the driver was ordered to desist from driving by the policeman, the omnibus was only a quarter of a mile from the defendants' yards, and there was an obvious possibility of communicating with the employers and by a reasonable endeavor obtaining their directions as to what was to be done. It seems to me, therefore, that there was no evidence to show that Harrison was an agent of

${ }^{17}$ [r895] 2 Q. B. 84. See Geargia Pac. R. Co. v. Propst, 85 Ala. 203, 4 So. 71 ; Fox 0. Railway Co., 86 Iowa, 368, 53 N. W. 259, 17 L. R. A. 289 . Upon the interesting question of the implied power of railway officials to employ medical and surgical assistance, see the discussion by Professor Hutchins in 2 Michigan Law Review, I. 
necessity so as to justify the putting up Veares to drive the omnibus, and, therefore, it not being within the scope of his employment to do so, the defendants are not responsible for Veares' negligence."

In Engelhart v. Farrant, ${ }^{18}$ also decided by the English Court of Appeal, in 1897, it appeared that the defendant, a merchant, entrusted his delivery cart and horse to a driver, one Mears, and also supplied one Tucker, a boy of seventeen, who went with the cart to deliver packages from it. Tucker had been forbidden to drive, and the court found that it was a proper inference that Mears knew that Tucker could not drive. Mears had also been cautioned against leaving the horse and cart unattended. While both were out with the cart delivering goods on a certain evening, the oil in the lamp of the cart gave out and Mears, instead of remaining with the cart and sending Tucker for more oil, left the cart with Tucker wnile he went into a house for oil. While he was gone, Tucker, to expedite the work, attempted to turn the cart around and in doing so negligently ran into the plaintiff's carriage and caused the injury for which the action was brought. There was held to be no doubt that it was negligent for the driver to leave the cart in charge of the boy, but it was seriously questioned whether that negligence was the proximate cause of the injury. The judges, however, agreed that it was. In his opinion, Iopes, I. J., said:-

"It was Mears's blameable carelessness which induced Tucker to do what he did. It was that carelessness which was the real moving and effective cause of the mischief, and I believe that is the inference which any jury would draw from the facts of this case.

"If Tucker had not been in the cart, and Mears had left the cart unattended, and the horse had moved on, and injury had been caused to a passer-by, or if a passer-by had jumped into the cart and driven it, and injured some person by negligent driving, the defendant would have been liable.

"Again, if Mears had asked a passer-by to stand at the head of the horse while he was absent, and the passer-by had left the horse, and the horse had gone on and injury had been caused to any person, the defendant would have been liable. Mears's carelessness in not anticipating what might not unreasonably happen would have been the real and effective cause of the mischief.

\footnotetext{
18 [I897] I Q. B. 240. Mann v. Ward, 8 Times L. Rep. 699, was criticised as being either incorrectly reported or unsound. According to the report of that case the licensed driver of defendant's cab became drunk, got into the cab and left it otherwise unattended on the street. While in this situation another man, also drunk, got on the cab and drove furiously along the street injuring the plaintiff. It was held that though the driver was guilty of negligence, his negligence was not the proximate cause of plaintiff's injury. "It was not the natural consequence of the defendant's driver getting drunk that another drunken man should get on the box and drive."
} 
"In this case Mears was practically leaving the horse and cart unattended. He knew Tucker was ordered not to interfere with the driving; he ought, therefore, to have anticipated that some casualty might happen, and it was his imprudence in this respect which caused the mischief."

Not unlike the last case is Leavenworth Electric Railroad Co. v. Cusick,19 decided by the Supreme Court of Kansas in r899. The plaintiff, a woman, was a passenger upon one of defendant's cars and told the conductor that she desired to get off at Pine street. The car was very full and the conductor, one Flora, being anxious to go inside to collect the fares, asked one Buckley, another conductor then off duty who happened to be on the car, to see that the plaintiff was let off at Pine street. When that street was reached Buckley gave the signal to stop and immediately left the car without waiting to see that plaintiff alighted. While she was in the act of alighting some one else gave the signal to.start, Flora, who was still inside the car, supposing it was Buckley and the motorman supposing it was Flora. The car started suddenly and plaintiff was thrown down and injured. It was urged by the defense that the injury was caused by the mere wrongful intermeddling of an outsider and that therefore the defendant was not responsible, and also that the company was not responsible for the negligence of Buckley. There was evidence that it was the custom among the conductors to assist one another in this way. The court held that if this custom was known to and acquiesced in by the company, then Buckley was the defendant's servant, and that it was negligence on his part not to see that the car was not started until plaintiff had alighted. If such custom was not a valid one, then it was negligence in Flora to abandon his duty in that regard or to depute its performance to another, and for such abandonment of duty by him the defendant was as much responsible as for the abandonment of the same duty by Buckley. Said the court, per Doster, C. J.:-

"If Flora rightly deputed the performance of his duties to Buckley, - that is, rightly as to the company-and Buckley negligently omitted to perform them, the company is liable. If Flora had no right to turn the performance of his duties over to Buckley, but nevertheless did so, he must be held to have negligently abandoned them, in which event the company is equally liable."

One of the most interesting and well considered of the cases in this connection is that of Haluptzok v. Great Northern Railway

\footnotetext{
19 6o Kan. 590, 57 Pac. 519, $72 \mathrm{Am}$. St. Rep. 374. "If the authority of adjudged cases be necessary to enforce these manifestly sound propositions, it can be found in Haluptzok v. Great Northern Ry. Co., 55 Minn. 446,57 N. W. 144 [infra] and Booth v. Mister, 7 Carr. \& Payne, 66 [supra]."
} 
Company, which came before the Supreme Court of Minnesota in I893. It there appeared that the Great Northern Railway Company, the Great Northern Express Company, and the Western Union Telegraph Company maintained a common office and agent at Waverley, Minn., one Westinghouse being the common agent of all three companies. For a year or more before the injury in question, Westinghouse had permitted a young man of the name of Foutch to practice upon the telegraph instruments in the office for the purpose of learning telegraphy, and during this time Foutch had assisted Westinghouse in the performance of his railway duties, such as selling tickets, handling freight, putting out lights, etc. He had no contract with the railway company, and received no wages. About ten days before the accident in question Westinghouse, with the permission of the Western Union Telegraph Company, had also given one O'Connell permission to use the telegraph instruments in the same way and for the same purpose. O'Connell had no contract with the defendant, and received no wages. On the day in question Foutch and $O^{\prime}$ Connell were engaged in moving goods from the station platform into the freight room, O'Connell handling the truck and Foutch assisting him in piling the goods upon it. While thus handling the truck, O'Connell ran it against the plaintiff's child and caused the injury for which recovery was sought of the railway company. The plaintiff recovered in the court below, and this recovery was affirmed by the Supreme Court, though upon grounds somewhat different from those relied upon in many of the cases above referred to. It was insisted that the defendant can be responsible only when the act in question can be regarded as the act of its servant, but it was held that, in view of all the circumstances in the case, there was sufficient evidence upon which the jury might find that both Foutch and O'Connell had been employed with at least the tacit consent of the railway company. In discussing the question, the court said:-

"Under the doctrine of respondeat superior, a master, however careful in the selection of his servants, is responsible to strangers for their negligence committed in the course of their employment. The doctrine is at best somewhat severe, and, if a man is to be held liable for the acts of his servants, he certainly should have the exclusive right to determine who they shall be. Hence, we think, in every well considered case where a person has been held liable, under the doctrine referred to, for the negligence of another, that

\footnotetext{
${ }^{20} 55$ Minn. 446,57 N. W. $\mathrm{r}_{44}, 26$ L. R. A. 739. - Upon the ground that the employment of the alleged sub-servants was known to and acquiesced in by the master, he was held liable in Wichtrecht $v$. Fasnacht, i7 La. Ann. 166, and Tennessee Coal Co. v. Hayes, 97 Ala. 20r, 12 So. 98 .
} 
other was engaged in his service either by the defendant personally, or by others by his authority express or implied. There is a class of cases, of which Bush v. Steinman, I Bos. \& P. 404 (often doubted and criticised), is an example, which seem to hold that a person may be liable for the negligence of another, not his servant. But these were generally cases where the injury was done by a contractor, sub-contractor or their servants, upon the real estate of the defendant, of which he was in possission and control, and they seem to proceed upon the theory that, where a man is in possission of fixed property he must take care that it is so used and managed by those whom he brings upon the premises as not to be dangerous to others. In that view, he is held liable, not for the negligence of another, but for his own personal negligence in not preventing or abating a nuisance on his own premises. There will also be found in some text-books statements to the effect that when a servant is employed to do a particular piece of work, and he employs another person to assist him, the master is liable for the acts of the person so employed, as much as for the acts of the servant himself. Thus generally stated, without qualification, the proposition is misleading, as well as inaccurate. The cases most generally cited in support of it are Booth v. Mister, and Althorf v. Wolfe."

The court then entered upon a discussion of these cases, declaring that the latter "is a very unsatisfactory one, and it is very difficult to ascertain the precise ground upon which it was decided."

"But neither of these cases, if rightly understoud, is in conflict with the proposition with which we started out,-that a master, as such, can be held liable for the negligence only of those who are employed in his work by his authority; and hence, if a servant who is employed to perform a certain work procures another person to assist him, the master is liable for the sole negligence of the latter, only when the servant had authority to employ such assistant. Such authority may, however, be implied as well as express, and subsequent ratification is equivalent to original authority; and, where the servant has authority to employ assistants, such assistants, of course, become the immediate servants of the master, the same as if employed by him personally. Such authority may be implied from the nature of the work to be performed, and also from the general course of conducting the business of the master for so long a time that knowledge and consent on the part of the master may be inferred. It is not necessary that a formal or express employment on behalf of the master should exist, or that compensation should be paid by or expected from him. It is enough to render the master liable if the person causing the injury was in fact render- 
ing service for him by his consent, express or implied." In pursuance of these principles, the court held, as has been stated, that there was evidence from which it might be found that Foutch and O'Connell had been employed with consent of the railway company. Said the court: "If the evidence were limited to the employment of O'Connell alone, and to what occurred during the ten days preceding the accident, it would probably be insufficient to support a verdict in favor of the plaintiff. But it is an undisputed fact that Westinghouse had for over a year before this been employing Foutch as an assistant under a similar arrangement, without, so far as appears, any objection on part of the defendant, although the length of time was such that its knowledge of the fact may be fairly inferred. It is true that implied authority to employ Foutch as assistant would not necessarily include authority to employ $O^{\prime} \mathrm{Con}$ nell, but the fact of Foutch's long-continued employment has an important bearing upon the question of Westinghouse's implied authority, as indicated by the manner of conducting the business; and, as bearing upon this same question of implied authority, the fact is significant that after the accident both Foutch and Q'Connell continued, without objection, to perform these services for defendant, as assistants to Westinghouse, up to the date of trial. Additional force is added to all this, when considered in connection with the nature of the duties of a station agent at a place like this, which are of such multifarious character as to render the employment of an occasional assistant not only convenient, but almost necessary. The facts that the consideration for the services of these assistants moved from Westinghouse, rather than defendant, and that their aid was for the accommodation or convenience of Westinghouse, are not controlling."

And finally, in a number of cases ${ }^{21}$ persons, who would ordinarily be regarded as independent contractors for the negligence of whose servants the employer would not be responsible, have, by reason of the reservation of an unusual power of control, been held to be mere servants for whose negligence and that of their servants the employer is liable. In these cases the employer and the servants of the person employed are contractually strangers. It would not be contended, for example, that the general employer could either hire, discharge or immediately direct them, nor would he be liable for their wages.

The foregoing embraces the most important of the cases which have been found dealing with the question in issue. There is a good

${ }_{21}$ See Atlantic Transport Co. v. Coneys, 28 C. C. A. 388, 82 Fed. Rep. 177; Railroad Co. $v$. Hanning, 15 Wall. (U. S). 649; Linnehan $v$. Rollins, I 37 Mass. 123, 50 Am. Rep. 287. 
deal of apparent conflict among them. Most of them, however, it -is believed, will be thought to have been rightly decided upon their special facts. A few are certainly questionable.

In dealing with them, the following considerations suggest themselves :-

The defendant, it is said, can be held liable only-

I. For his own default, or

II. For the default of his servant.

I. In the first class, there may be many cases in which he may be held liable because the primary fault was his own, even though the wrongful act of a stranger may have contributed to cause the injury. Thus, without attempting to be exhaustive, he may be liable-

I. For dangerous or noisome practices which go on upon his premises with his express or implied consent, whether the technical relation of master and servant exists between him and those upon his premises, or not. ${ }^{22}$

2. If he causes dangerous work to be done without taking reasonable precautions against injury even through the intermeddling of third persons. ${ }^{23}$

3. If he leaves dangerous agencies without guarding reasonably against their being put in motion even by a stranger or wrongdoer. $^{24}$

4. If he owes the performance of a positive duty and entrusts the performance of it to a servant who, instead of performing it himself, wrongfully relies upon some other person to perform it. ${ }^{25}$

II. Except in such cases, the master can be liable only when the act causing the injury was the act of his servant within the scope of his employment. He is not responsible for the act of a mere volunteer or a mere gratuitous inter-meddler however much his act was designed to or in fact did contribute toward promoting the master's business.

One may become the servant of another-

I. By the latter's personal appointment, which may be-

a. Express, or

"2 See Beaulieu v. Finglam, 2 H. IV., 18, p. 6; I Beven on Negligence, p. 481, et seq.

${ }^{23}$ See Illidge v. Goodwin, 5 C. \& P. 190.

${ }^{24}$ See Salisbury v. Erie R. Co., 66 N. J. L. 233, 50 Atl. I17; Smith v. Railroad Co., 46 N. J. L. 7; Southern Pac. R. Co. v. Lafferty, 57 Fed. 536; Fredericks v. Nor. Cent. Ry. Co., 157 Pa. 103, 27 Atl. 689.

${ }_{25}$ See Leavenworth Elec. R. Co. v. Cusick, supra; Lakin v. Oregon Pac. R. Co., supra. 
b. Tacit, as where one knowingly permits another not actually employed to assume the relation of a servant. ${ }^{20}$

2. By appointment by one to whom that power has been delegated. ${ }^{27}$ One servant has ordinarily no implied power to appoint sub-servants for his master, but such power may be given-

a. Expressly.

$b$. Impliedly, as where one servant is called upon to do work of such a sort or under such circumstances that the employment of assistants on the master's account is either necessary, usual, or contemplated. Possibly, also, when "necessity" demands it, as where some sudden emergency arises rendering it impossible to do what was originally intended but making it necessary that something be done, and the master is not where he can be communicated with for further instructions. ${ }^{2 s}$

c. By subequent ratification, though not authorized at the time.

When a person has been appointed in one of these ways, he of course becomes the servant of the person appointing and the latter assumes the responsibility of a master.

If the person who did the act complained of was not a servant within these rules, then, in order to hold the master liable, it is ordinarily necessary to see that the act, though physically performed by a stranger, was, in fact and in law, the act of the servant within the scope of his employment; or, at least, was caused by the neglect of the servant while acting within the scope of his employment.

Under this principle, two propositions may be stated :-

I. The servant may, within a very narrow field, use another person so clearly as a mere instrument-a longer arm, which the servant wields and controls-that the act of that person is to be regarded as the act of the servant, and, if negligent, as the negligence of the servant, so as to make the master liable. ${ }^{29}$ Where the act which the servant thus causes or directs is in itself negligent, there could ordinarily be little doubt of the liability; but even where the fault lies rather in the manner in which the person so used has done the act, the liability may attach.

The limits of this doctrine must be narrow; it can probably be applied only when the servant is on the ground directing and con-

\footnotetext{
${ }^{20}$ See Hill $v$. Morey, $26 \mathrm{Vt} .178$.

- ${ }^{27}$ See per Thesiger J. De Bussche $\nu$. Alt, 8 ChoD. 286, 310 ; Bodine v. Insurance Co., 5 I N. Y. 117, 10 Am. Rep. 566; Arff $v$. Star F. Ins. Co., I25 N. Y. 57, 25 N. E. 1073, 10

L. R. A. 609, 21 Am. St. Rep. 721.

${ }^{2 s}$ See Gwilliam v. Twist, supra.

$z^{a}$ See Booth $v$. Mister, supra; Simons v. Monier, supra; Appel v. Eaton, supra; James v. Muehleback, - supra; Hill v. Sheehan, supra.
} 
trolling the act, and so personally and immediately in charge that the act of the third person may fairly be regarded as the act of the servant.

The act itself must also in any event be an act within the scope of the servant's employment.

2. In some cases the failure of the servant to perform the act in person and his attempt to act through another are, in themselves, such negligence as to make the master responsible for what naturally and proximately follows as the result of his abdication of his duty.

The difficulty here has been to see the causal connection between the failure of the servant to act in person and the injury complained of, but in several cases it has been held to exist. ${ }^{30}$

The cases wherein the doctrine has thus far been applied have been chiefly those wherein the servant has entrusted the performance of some important duty to a person known to be incompetent, or has omitted to personally perform a duty requiring special care without seeing that it was performed by his substitute. It is doubtless a doctrine of somewhat narrow application to special facts.

But may we also go further, and say-

3. That the master, in directing the act to be done, has, from its nature and the circumstances under which it is to be done, impliedly authorized the servant to do it by means of the usual or proper tools or agencies, and that among those proper tools or agencies may be the casual act of a third person, not as a mere mechanical aid or longer arm as above suggested, nor yet in such a way as to make that third person, in any contractual sense at least, the master's servant (under II, $2, b$. supra), but merely as a permissible tool for whose defective working under the hand of the servant the master has impliedly assumed responsibility as he has for the working of the inanimate tools or agencies that may be employed?

Under such a rule, if, in the progress of the work, it became necessary to use a crowbar, the servant might use one; and if it became desirable or necessary to use the casual and incidental act of a third person, the servant might do that. If, in-such a case, the servant negligently selected an improper crowbar or carelessly used a proper one, the master would be liable. So if in such a case he negligently selected an improper person or negligently used a proper one, the master would be liable. But suppose he selects what appears to be an entirely proper crowbar, but, through some secret defect, it gives way and causes injury. Here the master pretty clearly would not be

${ }^{\circ}$ See Englehart $\approx$. Farrant, supra; Leavenworth Elec. R. Co. v. Cusick, supra. 
liable unless it was improper to use any crowbar at all. Now suppose he selects what appears to be an entirely proper person, and that person through a secret defect of weakness gives way and causes injury. Is the master liable? Pretty certainly not. But suppose he selects an apparently proper person and that person through-a secret vice of carelessness causes an injury. Is the master liable? If we say yes, as we pretty certainly will, it is because we must distinguish between the range of defects likely to occur in animate tools and inanimate ones. Something of this sort we are constantly doing. If I tie my horse by an apparently safe strap to an apparently safe hitching-post, and he nevertheless, through a secret defect in strap or post, breaks away and does injury, I am not liable. But if I leave him to be held by an apparently safe person and that person, through a secret vice of carelessness, negligently permits him to escape and he does injury, I am liable.

And now, lastly, inasmuch as the master may consent to the employment of sub-servants on such terms as he sees fit to impose, may we say-

4. That the master may impliedly authorize the servant to employ sub-servants on his, the servant's, account but not as servants of the master in such wise as to create privity of contract between such sub-servants and the master, but still in such wise as to make the master responsible for the negligence of that sub-servant committed in the execution of the work and within the scope of the servant's employment? In other words, may not the master sometimes be liable for the negligence of his servant's servants, without at the same time being himself the master of the servant's servant? In such a case, as between master and servant, the servant would be responsible to his master for the acts of the sub-servant and . bound to indemnify the master against the consequences of his acts; but, as between the master and a third person injured by the negligence of such sub-servant in the performance of the work, the master would be liable, because it was the result of the negligence of one doing his work with his implied consent.

Mr. Tiffany, ${ }^{31}$ after dealing with the cases wherein the agent may appoint a sub-agent in such a way as to create privity of contract between the principal and the sub-agent, has expressed a view respecting agents similar to the one now suggested in the case of the servant, thus:-

"On the other hand, the principal may authorize the employment of a sub-agent simply on the agent's behalf; that is, at the agent's

${ }^{31}$ Tifiany on Agency, p. I24. 
risk, and upon his responsibility. In such a case the principal is, of course, bound by the acts of the sub-agent because he has consented to be bound by them; but no privity of contract is created between him and the sub-agent because he has not authorized the agent to make a contract of employment to which he, the principal, shall be a party. Privity of contract in such case exists only between the agent and the sub-agent, and the agent is responsible [to the principal?] for the acts and defaults of the sub-agent, because such was the intention of the principal and the undertaking of the agent."

If by "the acts of the sub-agent" for which the principal is bound is meant not merely authorized acts-the doing of the particular act authorized in the manner contemplated, but negligent acts collateral or incidental to the authorized act, then the case is entirely parallel to the one suggested.

The relation of the servant under the circumstances here indicated approaches that of an independent contractor, but is not identical with it. The servant does not exercise an independent employment, and his master has, all of the time, that right of supervision and control which makes one responsible for the negligence of the actor and those whom he employs. ${ }^{32}$

It is, of course, not necessary to attempt either of the last two statements if the case may be brought within the rules previously given permitting the appointment of a sub-servant as the servant of the master (See II, 2,b.). The problem arises only when it is thought that a substitute may be employed in such wise as to make the master responsible for his negligence without also creating privity of contract between such substitute and the master.

If it be urged that these rules tend to unduly enlarge the sphere of the master's liability, it may be replied that it is not designed by any of them to hold him liable for the acts of a substitute or subservant unless the latter was expressly or impliedly appointed either by the master himself or by his express or implied authority, or unless he was employed or set in motion upon the master's business by the master's servant while acting within the scope of his employment,-or, to put the latter alternative in another form, unless he was employed or set in motion upon the master's business by the master's servant with the master's express or implied consent.

Untversity of Chicago.

FLOYD R. MECHEM.

32 See Railroad Co. v. Hanning, 15 Wall. (U. S.) 649; Linnehan v. Rollins, I37 Mass. 123. 50 Am. Rep. 287; Atlantic Transport Co. v. Coneys, 28 C. C. A. 388,82 Fed. Rep. 177. 